\title{
Intestinalis zsírsavkötő fehérje: az enterocytakárosodás markere akut és krónikus gasztroenterológiai kórképekben
}

\author{
Kocsis Dorottya dr. ${ }^{1}$ - Papp Mária dr. ${ }^{2}$ - Tornai Tamás dr. ${ }^{2}$ \\ Tulassay Zsolt dr. ${ }^{1}$ - Herszényi László dr. ${ }^{1}$ \\ Tóth Miklós dr. ${ }^{1}$ - Juhász Márk dr. ${ }^{1}$
}

\begin{abstract}
${ }^{1}$ Semmelweis Egyetem, Általános Orvostudományi Kar, II. Belgyógyászati Klinika, Budapest ${ }^{2}$ Debreceni Egyetem, Általános Orvostudományi Kar, Belgyógyászati Intézet, Gasztroenterológiai Tanszék, Debrecen
\end{abstract}

\begin{abstract}
Az intestinalis zsírsavkötő fehérje a zsírsavkötő fehérjék családjába tartozó, a vékony- és vastagbél enterocytáinak citoszoljában termelődő, kis molekulasúlyú fehérje. Az enterocytasejtek membránintegritásának megbomlását követően megjelenik a szisztémás keringésben, és a vesék glomerularis szürőjén keresztül kiválasztódik a vizeletbe. A szerzők akut és krónikus enterocytakárosodással járó gastrointestinalis kórképekben az intestinalis zsírsavkötő fehérje biomarkerként való használatával kapcsolatos vizsgálatokat tekintik át. Orv. Hetil., 2016, 157(2), 59-64.
\end{abstract}

Kulcsszavak: intestinalis zsírsavkötő fehérje, nekrotizáló enterocolitis, akut mesenterialis ischaemia, coeliakia, gyulladásos bélbetegség, bakteriális transzlokáció

\section{Intestinal fatty acid binding protein: marker of enterocyte damage in acute and chronic gastroenterological diseases}

\begin{abstract}
Intestinal fatty acid binding protein, a small cytosolic protein abundantly present in mature enterocytes of small and large intestine, has proven to be a sensitive marker for damage to the intestinal epithelium. Upon cellular damage of the enterocyte, intestinal fatty acid binding protein is readily released into the systemic circulation, passes through the glomerular filter and can be detected in the urine. In this review, the authors review studies on the application of this protein as a biomarker in acute and chronic gastrointestinal diseases.
\end{abstract}

Keywords: intestinal fatty acid binding protein, necrotizing enterocolitis, acute mesenteric ischaemia, celiac disease, inflammatory bowel disease, liver cirrhosis

Kocsis, D., Papp, M., Tornai, T., Tulassay, Zs., Herszényi, L., Tóth, M., Juhász, M. [Intestinal fatty acid binding protein: marker of enterocyte damage in acute and chronic gastroenterological diseases]. Orv. Hetil., 2016, 157(2), 59-64.

(Beérkezett: 2015. október 18.; elfogadva: 2015. november 12.)

\section{Rövidítések}

$\mathrm{BT}=$ bakteriális transzlokáció; $\mathrm{CD}=($ Crohn's disease $)$ Crohnbetegség; CDAI $=($ Crohn's disease activity index $)$ Crohn-betegség-aktivitási index; $\mathrm{CRP}=\mathrm{C}$-reaktív protein $; \mathrm{CU}=$ colitis ulcerosa; $\quad$ ELISA = enzyme-linked immunosorbent assay; I$\mathrm{BABP}=($ ileal bile acid binding protein $)$ ilealis epesavkötő fe- hérje; I-FABP $=$ (intestinal fatty acid binding protein $)$ intestinalis zsírsavkötő fehérje; L-FABP = (liver fatty acid binding protein) máj zsírsavkötő fehérje; LMWH = (low molecular weight heparin) kis molekulasúlyú heparin; MELD = Model For End-Stage Liver Disease; NEC = nekrotizáló enterocolitis 
Szövetkárosodást követően a plazmában megjelenő sejteredetú proteinek biológiai markerként fontos szerepet játszanak a sérülés diagnosztikájában. A szöveti károsodás detektálásában ígéretes új biomarkereknek tartják a fatty acid bindig proteins (FABP) családba tartozó fehérjéket. Ezek a kis molekulasúlyú (14-15kDa), 126137 aminosavból álló proteinek az aktív zsírsavlebontást végző szövetek sejtjeinek citoplazmájában találhatóak meg, sejten belül fél életidejük körülbelül 2-3 nap. Elsődleges feladatuk a hosszú láncú zsírsav intracelluláris transzportjának elősegítése [1]. A FABP-szintézis szabályozása transzkripciós szinten történik, érzékenyen reagálva a lipidmetabolizmust befolyásoló élettani és farmakológiai ingerekre, mint az ischaemia, erôs fizikai igénybevétel, diabetes vagy lipidcsökkentő gyógyszerek. A FABP-családnak a mai napig 9 különböző tagját sikerült azonosítani, mindegyik típus jellegzetes szöveti eloszlást mutat. Elnevezésüket arról a szövetről kapták, ahol először sikerült őket kimutatni $[2,3]$. Szöveti sérülést követően a FABP-fehérjék keringésben történő megjelenésének ideje függ a molekula méretétől, az érendothel áteresztőképességétől, illetve a károsodásért felelős kórkép lefolyásától [4].

\section{Intestinal fatty acid binding protein - I-FABP}

Tanulmányok igazolták, hogy az intestinalis epithelsejtek károsodását követően a keringésben, illetve a vizeletben is kimutathatók zsírsavkötő proteinek. Bélrendszerünkben a FABP-család három szubtípusa van jelen: intestinalis FABP (I-FABP), máj-FABP (liver fatty acid binding protein - L-FABP) és az ileumepesav-kötő fehérje (ileal bile acid binding protein - I-BABP) [2]. Pelsers és munkatársainak szövettani vizsgálatai igazolták, hogy az I-FABP kimutatható mind a vékony-, mind pedig a vastagbél epithelsejtjeinek citoszoljában. A vékonybél I-FABP-tartalma ugyanakkor lényegesen meghaladja a vastagbélben mérhető I-FABP-szintet. Legnagyobb mennyiségben a jejunumban szintetizálódik, körülbelül 20-szor annyi, mint a vastagbélben [5]. Derikx és mtsai az L-FABP eloszlását vizsgálva egészséges emberi gyomor-bél traktusban, az I-FABP-hoz hasonlóan, a legmagasabb koncentrációt a jejunumban, a legalacsonyabbat a colonban mérték, míg a duodenumban, illetve az ileumban közel azonos koncentrációt találtak [6]. Immunhisztokémiai vizsgálatok alapján az I-FABP és L-FABP a vékonybélben csak a bélbolyhok érett enterocytáiban és kehelysejtjeiben képződik, a crypták sejtjeiben nem. Egészséges vastagbélben I-FABP- és L-FABP-pozitív immunfestődés csak a crypták felső felében lévő epithelsejtekben volt kimutatható, a crypták alsó felét alkotó sejtekben nem [7]. Az enterocytasejtek membránintegritásának megbomlásához vezető károsodás esetén az I-FABP szinte azonnal megjelenik a szisztémás keringésben. Meghatározása I-FABP-ellenes antitestek használatával, kvantitatív ELISA- (enzyme-linked immuno- sorbent assay) módszerrel történik. Az alacsony molekulatömegú I-FABP a szisztémás keringésből a vesék glomerularis szűrőjén keresztül kiválasztódik (frakcionált renalis exkréció $28 \%$; felezési idő 11 perc), ily módon kimutathatóvá válik a vizeletben is [8].

\section{Akut enterocytakárosodással járó kórképek}

\section{Nekrotizáló enterocolitis, akut mesenterialis ischaemia}

A nekrotizáló enterocolitis (NEC) általában koraszülöttekben, hypoxia és infekció egyettüseként létrejövő, a béltraktusban kialakuló súlyos gyulladás, amely a bélfal infarktusához, perforációjához, esetleg teljes bélnecrosishoz vezethet. Mortalitása $20-40 \%$ közötti. A patogenezis csak részben ismert. Feltételezik, hogy a perinatalis stressz, hypoxia a bélnyálkahártya keringési zavarát idézi elő [9]. Korai szakaszban a nekrotizáló enterocolitis tünetei nem specifikusak (puffadás, táplálási nehezítettség), így a diagnózis felállítása nehézséget jelenthet a kezelőorvos számára. Ezt tovább nehezíti a jelenleg használt laboratóriumi és radiológiai vizsgálatok korlátozott diagnosztikai pontossága $[10,11]$. Kórszövettanilag a NEC-et a bélfal koagulációs vagy ischaemiás nekrózisa jellemzi, ami a mucosán kezdődik és ráterjed a submucosára, majd a muscularis externára. A mucosasérülés hatására felszabaduló I-FABP a vérből és a vizeletből már korai NEC esetén is detektálható, szintje emelkedett az egészséges kontrollszemélyekben mért értékekhez képest. Ezt elsőként Lieberman és mtsai írták le 1997-ben, majd több vizsgálat is igazolta, hogy NECben a nem specifikus emésztőrendszeri tünetek fellépését követő első nyolc órában mért I-FABP-értékek hasznos diagnosztikus és prognosztikus faktorok lehetnek [1216]. Schurink és mtsai szignifikánsan magasabb kezdeti plazma-I-FABP-szintet mértek azoknál a NEC-es csecsemőknél, akiknél később sebészeti beavatkozásra volt szükség, szemben a konzervatív terápiával kezelhető csecsemőkben mért kezdeti plazma-I-FABP-értékekkel [17].

Mivel az I-FABP-molekulák jelentős bomlás nélkül képesek kiválasztódni a vizeletbe, a vizeletből történő meghatározásuk megfelelő küszöbérték meghatározása mellett kellően specifikus, jó alternatíváját jelentheti a vérvizsgálatnak. Előnye, hogy nem jár többletterheléssel a csecsemók számára, és a hólyagban tárolt vizelet lehetővé teszi az I-FABP meghatározását azt követően is, hogy az a vérból már kiürült $[8,12,15]$.

$\mathrm{Az}$ akut mesenterialis ischaemia a zsigeri erek elzáródása (occlusiv zavar 70\%: artériás embólia, artériás/vénás trombózis) vagy csökkent véráramlás (nonocclusiv zavar 30\%: cardiogen/hypovolaemiás sokk, szív- és hasi mútétek, dialízis, aortainsufficientia, vasoconstrictiv gyógyszerek stb.) miatt kialakuló, életet veszélyeztető kórkép. A vékonybél ischaemiás toleranciája 6 óra, ezt követően irreverzibilisen károsodik, ezért a korai diagnózis létfon- 
tosságú. Néhány humán vizsgálat során sikerült igazolni, hogy a szérum-I-FABP szintje megemelkedik az arteria mesenterica superior occlusiója esetén $[8,15,18-21]$. Egy patkányokat használó kísérletes modellben az SE I. Sebészeti Klinika munkacsoportja kimutatta, hogy a szérum-I-FABP szintjének emelkedése jól korrelál a szövettani minták elemzése során talált intestinalis epithelsejtkárosodás mértékével [22]. Mindezek alapján az I-FABP hasznos biomarker lehet az ischaemiás vékonybél-károsodás korai diagnosztikájában is.

\section{Krónikus enterocytakárosodással járó kórképek}

\section{Coeliakia, Morbus Crohn, májcirrhosis}

A coeliakia (gluténszenzitív enteropathia) a lakosság több mint $1 \%$-át érintő immunmediált szisztémás kórkép, amelyet a gabonafélék (búza, rozs, árpa) prolaminjai, leggyakrabban a glutén, idéznek elő genetikailag fogékony egyénekben. Főbb jellemzői a változatos intestinalis és extraintestinalis tünetek, az enteropathia, coeliakiaspecifikus antitestek jelenléte, valamint a HLADQ2 vagy -DQ8 haplotípus hordozása. A coeliakia diagnózisának felállításához a diétanaiv betegnél szerológiai (szöveti transzglutamináz - tTG, endomysiumellenes antitest - EMA, deamidált gliadin peptid - DGP) és szövettani vizsgálat szükséges. A coeliakia diagnózisát követően egész életen át tartó, gluténmentes diéta követésére van szükség, ezzel megelőzendő a leggyakoribb szövődmények, a csontsűrűség csökkenését és a lymphomák kialakulását.

Elsőként Derikx és mtsai vizsgálták az I-FABP plazmaszintjét frissen diagnosztizált coeliakiás betegben. Egészséges kontrollszemélyekben mért értékekkel összehasonlítva a kapott eredményeket, a még nem kezelt lisztérzékeny betegben az I-FABP-szint 4,5-szer magasabbnak bizonyult. A jelenleg használatban lévő szerológiai markerek jól használhatóak a gluténmentes diéta effektivitásának monitorozására, ugyanakkor a vékonybélnyálkahártya-károsodás diéta hatására történő javulásáról nem nyújtanak kellő információt. Derikx és mtsai 10 coeliakiás betegnél vizsgálták a gluténmentes diéta hatását a szérum-I-FABP-szintre, és úgy találták, hogy 1 éves szigorú gluténmentes diétát követően a szérum-IFABP-értékek szignifikánsan csökkentek, kilenc esetben a küszöbérték alá. A szerológiai markerek mind a tíz esetben a normáltartományban voltak. Egy beteg esetében a szérum-I-FABP-szint 1 év diétát követően is meghaladta a küszöbértéket, ennél a betegnél a további vizsgálatok refrakter coeliakiát igazoltak [6]. Adriaanse és mtsai 80 kezeletlen coeliakiás beteget és 141 kontrollszemélyt vizsgálva a coeliakiások körében szignifikánsan emelkedett I-FABP-szinteket mértek. A diagnózis időpontjában mért I-FABP-értékek jól korreláltak a szövettani minták Marsh-klasszifikáció szerinti beosztásával (azaz a boholysorvadás mértékével), és a szérum-tTG-
IgA-szintekkel. Hatvankilenc coeliakiás betegnél a gluténmentes diéta megkezdése után 3 éven át követték a szérum-I-FABP-szint változását. Hat hónap diéta után az I-FABP-szintek szignifikánsan csökkentek, a 6. és 12. hónap között az értékek tovább csökkentek, de a változás már nem volt szignifikáns. Gluténmentes diéta követése mellett a szérum-I-FABP-értékek az 1-2. év között egy platószintre álltak be, nem csökkentek tovább. Az ekkor mért értékek felette voltak a kontrollcsoportban meghatározott szérum-I-FABP-normáltartománynak, annak ellenére, hogy a diétával kezelt betegekben az ismételt szerológiai vizsgálat negatív volt, a szövettan pedig egyértelmú javulást (Marsh 0-1) mutatott. Feltételezik, hogy coeliakiás betegeknél a gluténmentes diéta ellenére fennállhat rutin szövettani vizsgálattal nem detektálható, csak elektronmikroszkóppal kimutatható, perzisztáló enterocytakárosodás, és ez tehető felelőssé a normáltartományt meghaladó I-FABP-szintért ezekben a betegekben [23]. Rodríguez-Martín és mtsai coeliakiás betegek elsőfokú rokonainál vizsgáltak szérum-I-FABPszintet, és a normáltartományhoz képest szignifikánsan emelkedett értékeket mértek azon elsőfokú rokonok körében, akiknél HLA-DQ2- vagy -DQ8-pozitivitás, genetikai hajlam volt kimutatható, negatív szerológia és szövettani lelet mellett. Lehetségesnek tartják, hogy ezen elsőfokú rokonok esetében a coeliakia szubklinikus formája áll fenn, amely az élet során aktív coeliakiába csaphat át, így ezen személyek követése, bizonyos időközönként elvégzett szerológiai szûrése coeliakia irányában megfontolandó [24, 25].

A Crohn-betegség (CD) autoimmun patomechanizmusú, krónikus gyulladásos bélbetegség, amely érintheti a gyomor-bél traktust a szájüregtôl a végbélnyílásig, s leggyakrabban a terminális ileumban alakul ki. A klinikai lefolyását aktív időszakok és remissziók jellemzik. A betegség aktivitásának meghatározására klinikai, endoszkópos, illetve labormarkereket egyaránt használnak. Az irodalomban mind ez idáig egyetlen közlemény foglalkozik a szérum-I-FABP vizsgálatával Crohn-betegekben. Sarikaya és mtsai $74 \mathrm{CD}$-beteget (4l aktív és 33 remisszióban lévő) és 37 egészséges kontrollszemélyt vontak be a vizsgálatukba. Szignifikánsan magasabb I-FABP-értéket mértek az aktív CD-s pácienseknél, összehasonlítva a remisszióban lévő CD-s betegeknél és a kontrollcsoportban mért értékekkel. Ugyanakkor a remisszióban lévő CD-s betegekben és a kontrollcsoportban mért I-FABPértékek között nem volt szignifikáns különbség kimutatható. Az aktív CD-ben mért I-FABP-értékek jól korreláltak a Crohn-betegség-aktivitási index (CDAI) és C-reaktív protein (CRP-) értékekkel. Az I-FABP-aktivitást jelző markerként való felhasználása Crohn-betegségben további vizsgálatokat igényel [26]. Az I-FABP-szintet aktív colitis ulcerosás betegekben vizsgálva, Wiercinska-Drapalo és mtsai a kontrollcsoportban detektált értékek közel háromszorosát mérték. Pancolitis, terminális ileumérintettség szignifikánsan magasabb I-FABP-szintet eredményezett, mint a bal colonfél gyul- 
ladásával járó forma. Ezáltal colitis ulcerosában az I-FABP-szint emelkedése a gyulladásos folyamat kiterjedésének markere lehet [27].

A bélnyálkahártya-barrier strukturális és funkcionális károsodása a bakteriális transzlokáció (BT) kialakulásában meghatározó tényező [28]. A BT pedig a májcirrhosis egyik fontos jellegzetessége, amely jelentősen hozzájárul a betegség kulcsfontosságú patogenetikai folyamataihoz, és így szerepet játszik mind az akut roszszabbodásban, mind pedig a betegség krónikus progressziójában. Májcirrhosisban a vékonybél jelentős gyulladásáról számoltak be, amely a betegség súlyosbodásával és a portalis hypertensio kialakulásával fokozódik [29, 30]. Kapszulaendoszkópián átesett májcirrhosisos betegek kétharmadában találtak gyulladásos nyálkahártya-eltéréseket [31]. Továbbá különféle morfológiai elváltozások is leírásra kerültek a vékonybélben, mint például részleges boholyatrophia, enyhe-közepes fokú lamina propria sejtes infiltráció és intraepithelialis lymphocytaszaporulat [32]. A bélbarrier integritásának károsodásáért a nyálkahártya vérátáramlásának megváltozása, az oxidatív stressz, a megnövekedett proinflam- matorikus citokinkoncentráció és a nitrogén-oxid felelösek elsősorban $[33,34]$.

Az I-FABP jelentőségét krónikus májbetegségben eddig mindössze 3 közleményben elemezték. Krónikus hepatitis C-vírus- (HCV-) és B-vírus- (HBV-) infekcióban szenvedő betegekben az egészséges egyénekhez képest magasabb I-FABP-szintről számoltak be, függetlenül a fibrosis mértékétől [35]. Az I-FABP szérumszintje öszszefüggést mutatott a portalis hypertoniára utaló laboratóriumi és képalkotó jelekkel, nevezetesen az alacsonyabb thrombocytaszámmal és a vena portae átmérőjével is $[35,36]$. Ezeket az indirekt adatokat ugyanakkor invazív hemodinamikai méréssel még nem támasztották alá. Továbbá összefüggés volt megfigyelhető a májkárosodás mértékével (GOT, GPT, bilirubinszint) és a máj szintetikus rezerv kapacitásának csökkenésével (INR, albumin) is, ennek megfelelően a májbetegség súlyosságát jelző Child-Pugh-stádiummal és a MELD-pontszámmal [35]. Ezek az adatok arra utalnak, hogy a májcirrhosis súlyosságával párhuzamosan az enterocytakárosodás mértéke is növekszik. Ötéves követéses vizsgálatban French és mtsai azt találták, hogy a májbetegség progressziójával - azaz a

1. táblázat | Irodalmi áttekintés az akut és krónikus gasztroenterológiai kórképekben detektált intestinalis zsírsavkötő fehérje (I-FABP-) szintekről

\begin{tabular}{|c|c|c|c|c|c|c|}
\hline $\begin{array}{l}\text { Közlemény } \\
\text { (év) }\end{array}$ & $\begin{array}{l}\text { Vizsgált } \\
\text { kórkép }\end{array}$ & Betegszám (n) & $\begin{array}{l}\text { Átlagos } \\
\text { szérum-I-FABP- } \\
\text { értékek, beteg }\end{array}$ & $\begin{array}{l}\text { Kontrollszemélyek } \\
\text { száma }(\mathrm{n})\end{array}$ & $\begin{array}{l}\text { Átlagos } \\
\text { szérum-I-FABP- } \\
\text { értékek, kontroll }\end{array}$ & $\begin{array}{l}\text { Használt } \\
\text { assay típusa }\end{array}$ \\
\hline \multirow{3}{*}{$\begin{array}{l}\text { Aydemir } \\
(2011)\end{array}$} & $\mathrm{NEC}$ & ${ }^{*}$ I. stádium $(\mathrm{n}=22)$ & $324,0 \pm 165,8 \mathrm{pg} / \mathrm{mL}$ & 31 & $76,9 \pm 115,9 \mathrm{pg} / \mathrm{mL}$ & ELISA (Hycult) \\
\hline & & II. stádium (n = 11) & $764,7 \pm 465,1 \mathrm{pg} / \mathrm{mL}$ & & & \\
\hline & & III. stádium (n = 8) & $360,2 \pm 439,5 \mathrm{pg} / \mathrm{mL}$ & & & \\
\hline $\begin{array}{l}\text { Schurink } \\
(2015)\end{array}$ & $\mathrm{NEC}$ & 17 & $\begin{array}{l}35 \mathrm{ng} / \mathrm{mL} \\
\text { (range: } 2,2-370)\end{array}$ & 15 & $\begin{array}{l}4,6 \mathrm{ng} / \mathrm{mL} \\
\text { (range: } 0,41-19 \text { ) }\end{array}$ & $\begin{array}{l}\text { ELISA } \\
\text { (R\&D system) }\end{array}$ \\
\hline Kanda (1996) & AMI & 5 & $\begin{array}{l}265,8 \mathrm{ng} / \mathrm{mL} \\
\text { (range: } 100-1496 \text { ) }\end{array}$ & 35 & $<65 \mathrm{ng} / \mathrm{mL}$ & $\begin{array}{l}\text { ELISA } \\
\text { (in house) }\end{array}$ \\
\hline Güzel (2014) & AMI & 30 & $\begin{array}{l}421 \mathrm{pg} / \mathrm{mL} \\
\text { (range: } 40-5000)\end{array}$ & 20 & $\begin{array}{l}20 \mathrm{pg} / \mathrm{mL} \\
\text { (range: } 1-90 \text { ) }\end{array}$ & ELISA (Hycult) \\
\hline Derikx (2009) & Coeliakia & 13 & $787,7 \pm 145,5 \mathrm{pg} / \mathrm{mL}$ & 26 & $172,7 \pm 20,2 \mathrm{pg} / \mathrm{mL}$ & ELISA (Hycult) \\
\hline $\begin{array}{l}\text { Adriaanse } \\
(2013)\end{array}$ & Coeliakia & 80 & $\begin{array}{l}691 \mathrm{pg} / \mathrm{mL} \\
\text { (interquartile range: } \\
447-1266 \text { ) }\end{array}$ & 141 & $\begin{array}{l}178 \mathrm{pg} / \mathrm{mL} \\
\text { (interquartile range: } \\
126-286 \text { ) }\end{array}$ & $\begin{array}{l}\text { ELISA } \\
\text { (in house) }\end{array}$ \\
\hline $\begin{array}{l}\text { Rodriguez- } \\
\text { Martín (2015) }\end{array}$ & Coeliakia & $\begin{array}{l}51 \text { (coeliakiás } \\
\text { betegek elsőfokú } \\
\text { rokonai HLA DQ2/ } \\
\text { DQ8 pozitivitással) }\end{array}$ & $427,18 \pm 164,6 \mathrm{pg} / \mathrm{mL}$ & $\begin{array}{l}16 \text { (coeliakiás } \\
\text { betegek elsőfokú } \\
\text { rokonai HLA } \\
\text { DQ2/DQ8 } \\
\text { negatív) }\end{array}$ & $324,95 \pm 108,1 \mathrm{pg} / \mathrm{mL}$ & $\begin{array}{l}\text { ELISA } \\
\text { (in house) }\end{array}$ \\
\hline $\begin{array}{l}\text { Wiercinska- } \\
\text { Drapalo (2008) }\end{array}$ & $\mathrm{CU}$ & 42 & $166,9 \pm 36,3 \mathrm{pg} / \mathrm{mL}$ & 20 & $61,3 \pm 7,8 \mathrm{pg} / \mathrm{mL}$ & ELISA (Hycult) \\
\hline Villa (2012) & Cirrhosis & 70 & $\sim 2100 \mathrm{pg} / \mathrm{mL}^{* *}$ & NA & NA & ELISA (Hycult) \\
\hline $\begin{array}{l}\text { Sandler } \\
(2011)\end{array}$ & $\begin{array}{l}\text { Májfibrosis/ } \\
\text { cirrhosis }\end{array}$ & 80 & $\sim 200 \mathrm{pg} / \mathrm{mL}^{* *}$ & 41 & $\sim 20 \mathrm{pg} / \mathrm{mL}$ & $\begin{array}{l}\text { ELISA } \\
\text { (Cell Sciences) }\end{array}$ \\
\hline French (2013) & $\begin{array}{l}\mathrm{HIV}+\mathrm{HCV} \\
\text { fertózöttek }\end{array}$ & 44 & $\begin{array}{l}476 \pm 378-927 \pm 799 \\
\mathrm{pg} / \mathrm{mL}\end{array}$ & NA & NA & ELISA (Hycult) \\
\hline
\end{tabular}

$\mathrm{AMI}=$ akut mesenterialis ischaemia $\mathrm{CU}=$ colitis ulcerosa; $\mathrm{NA}=$ nincs adat $\mathrm{NEC}=$ nekrotizáló enterocolitis .

*Nekrotizáló enterocolitis Walsh és Kliegman szerinti beosztása alapján [16].

**Az értékek megadása grafikus leolvasás alapján történt. 
betegségspecifikus szövődmények kialakulásával - egyidejűleg az I-FABP szérumszintje is nőtt [37]. Érdekes módon krónikus HCV-ben szenvedő betegekben sikeres kezelést követően az I-FABP szintje jelentősen csökkent [35]. Villa és mtsai randomizált, kontrollált klinikai vizsgálatban elemezték, hogy májcirrhosisos betegekben 1 éven keresztül profilaktikus dózisban kis molekulasúlyú heparint (LMWH) alkalmazva megelőzhető-e a vena portae thrombosis kialakulása. A tanulmány az LMWH kedvező hatását mutatta, ugyanakkor egy érdekes melléklelet is bemutatásra került, amely szerint az LMWH alkalmazását követően a BT markerei és az I-FABP szérumszintje is szignifikánsan csökkentek [36]. Ennek az lehet a magyarázata, hogy a portalis hypertensio következtében a bél mikrocirkulációja megváltozik, microthrombusok alakulnak ki, amelyek az enterocyták ischaemiás károsodásához vezetnek. Májcirrhosisban a béltraktus hámjának károsodásával együtt a BT fokozódik [28]. Felmerül annak a kérdése, hogy a szérum-IFABP-szint, mint a bélfalkárosodást jelző marker, használható-e a betegség lefolyásának előrejelzésében. Bár a fent említett kórélettani kapcsolatok világosak, az IFABP-t erre valószínúleg nem lehet majd használni, ugyanis a kórlefolyás szempontjából stabil és a szövődményes betegek kezdeti I-FABP-szintje nem különbözött egyik tanulmányban sem, ez azonban további vizsgálatokat igényel még $[35,37]$.

\section{Következtetések}

A zsírsavkötő fehérjék családjába tartozó, a vékony- és vastagbél enterocytáiban termelődő I-FABP a bélkárosodás szérumból és vizeletből is kimutatható markere (1. táblázat). Akut enterocytakárosodással járó kórképnél, mint a NEC és az akut mesenterialis ischaemia, a gyors diagnózisfelállításban, a prognózis megítélésében lehet döntő szerepe. A krónikus enterocytakárosodást okozó megbetegedésekben, mint a coeliakia vagy a Crohn-betegség, a diagnosztikában az I-FABP-nak csak kiegészítő szerep jut. Jelentősége inkább a betegségek követésében mutatkozik meg: coeliakiában a vékonybélnyálkahártya-károsodás diéta hatására történő javulásáról nyújthat információt, míg Crohn-betegségben, colitis ulcerosában, illetve májcirrhosishoz társult bakteriális transzlokációban aktivitást jelző marker lehet.

Anyagi támogatás: A közlemény megírása anyagi támogatásban nem részesült.

Szerzői munkamegosztás: K. D., J. M., P. M., T. T.: Irodalomkutatás és a kézirat megszövegezése. T. Zs., H. L., T. M.: A kézirat felülvizsgálata, megszövegezése. A cikk végleges változatát valamennyi szerző elolvasta és jóváhagyta.

Érdekeltségek: A közleménnyel kapcsolatban a szerzőknek nincsenek érdekeltségeik.

\section{Irodalom}

[1] Storch, J., Thumser, A. E.: The fatty acid transport function of fatty acid-binding proteins. Biochim. Biophys. Acta, 2000, 1486(1), 28-44.

[2] Pelsers, M. M., Hermens, W. T., Glatz, J. F.: Fatty acid-binding proteins as plasma markers of tissue injury. Clin. Chim. Acta, 2005, 352(1-2), 15-35.

[3] Schaap, F. G., van der Vusse, G. J., Glatz, J. F.: Evolution of the family of intracellular lipid binding proteins in vertebrates. Mol. Cell. Biochem., 2002, 239(1-2), 69-77.

[4] Hermens, W. T.: Mechanisms of protein release from injured heart muscle. Dev. Cardiovasc. Med., 1998, 205, 85-98.

[5] Pelsers, M. M., Namiot, Z., Kisielewski, W., et al.: Intestinal-type and liver-type fatty acid-binding protein in the intestine. Tissue distribution and clinical utility. Clin. Biochem., 2003, 36(7), 529-535.

[6] Derikx, J. P., Vreugdenhil, A. C., Van den Neucker, A. M., et al.: A pilot study on the noninvasive evaluation of intestinal damage in celiac disease using I-FABP and L-FABP. J. Clin. Gastroenterol., 2009, 43(8), 727-733.

[7] Levy, E., Ménard, D., Delvin, E., et al.: Localization, function and regulation of the two intestinal fatty acid-binding protein types. Histochem. Cell Biol., 2009, 132(3), 351-367.

[8] Derikx, J. P., Evennett, N. J., Degraeuwe, P. L., et al.: Urine based detection of intestinal mucosal cell damage in neonates with suspected necrotising enterocolitis. Gut, 2007, 56(10), 1473-1475.

[9] Lin, P. W., Stoll, B. J.: Necrotising enterocolitis. Lancet, 2006, 368(9543), 1271-1283.

[10] Fanaroff, A. A., Korones, S. B., Wright, L. L., et al.: Incidence, presenting features, risk factors and significance of late onset septicemia in very low birth weight infants. The National Institute of Child Health and Human Development Neonatal Research Network. Paediatr. Infect. Dis. J., 1998, 17(7), 593-598.

[11] Hällström, M., Koivisto, A., Janas, M., et al.: Laboratory parameters predictive of developing necrotizing enterocolitis in infants born before 33 weeks of gestation. J. Pediatr. Surg., 2006, 4l(4), 792-798.

[12] Lieberman, J. M., Sacchettini, J., Marks, C., et al.: Human intestinal fatty acid binding protein: Report of an assay with studies in normal volunteers and intestinal ischemia. Surgery, 1997, $121(3), 335-342$.

[13] Edelson, M. B., Sonnino, R. E., Bagwell, C. E., et al.: Plasma intestinal fatty acid binding protein in neonates with necrotizing enterocolitis: a pilot study. J. Pediatr. Surg., 1999, 34(10), 14531457.

[14] Guthmann, F., Börchers, T., Wolfrum, C., et al.: Plasma concentration of intestinal- and liver-FABP in neonates suffering from necrotizing enterocolitis and in healthy preterm neonates. Mol. Cellular Biochem., 2002, 239(1-2), 227-234.

[15] Thuijls, G., van Wijck, K., Grootjans, J., et al.: Early diagnosis of intestinal ischemia using urinary and plasma fatty acid binding proteins. Ann. Surg., 2011, 253(2), 303-308.

[16] Aydemir, C., Dilli, D., Oguz, S. S., et al.: Serum intestinal fatty acid binding protein level for early diagnosis and prediction of severity of necrotizing enterocolitis. Early Hum. Dev., 2011, $87(10), 659-661$.

[17] Schurink, M., Kooi, E. M., Hulzebos, C. V., et al.: Intestinal fatty acid-binding protein as a diagnostic marker for complicated and uncomplicated necrotizing enterocolitis: a prospective cohort study. PLoS ONE, 2015, 10(3), e0121336.

[18] Güzel, M., Sözüer, E. M., Salt, Ö., et al.: The value of the serum I-FABP level for diagnosing acute mesenteric ischemia. Surg. Today, 2014, 44(11), 2072-2076.

[19] Matsumoto, S., Sekine, K., Funaoka, H., et al.: Diagnostic performance of plasma biomarkers in patients with acute intestinal ischaemia. Br. J. Surg., 2014, 101(3), 232-238. 
[20] Kanda, T., Fujii, H., Tani, T., et al.: Intestinal fatty acid-binding protein is a useful diagnostic marker for mesenteric infarction in humans. Gastroenterology, 1996, 110(2), 339-343.

[21] Kanda, T., Tsukahara, A., Ueki, K., et al.: Diagnosis of ischemic small bowel disease by measurement of serum intestinal fatty acid binding protein in patients with acute abdomen: a multicenter, observer-blinded validation study. J. Gastroenterol., 2011, $46(4), 492-500$

[22] Rosero, O., Ónody, P., Kovács, T., et al.: Impaired intestinal mucosal barrier upon ischemia-reperfusion: "Patching holes in the shield with a simple surgical method". BioMed Res. Int., 2014, 2014, 210901

[23] Adriaanse, M. P., Tack, G. J., Passos, V. L., et al.: Serum I-FABP as marker for enterocyte damage in coeliac disease and its relation to villous atrophy and circulating autoantibodies. Aliment. Pharmacol. Ther., 2013, 37(4), 482-490.

[24] Rodriguez-Martín, L., Vaquero, L., Vivas, S.: Letter: serum IFABP as marker for enterocyte damage in first-degree relatives of patients with coeliac disease. Aliment. Pharmacol. Ther., 2015, 42(1), 121-122.

[25] Adriaanse, M. P., Bunrman, W. A., Vreugdenbil, A. C.: Letter: serum I-FABP as marker for enterocyte damage in first-degree relatives of patients with coeliac disease - authors' reply. Aliment. Pharmacol. Ther., 2015, 42(1), 122.

[26] Sarikaya, M., Ergül, B., Doğan, Z., et al.: Intestinal fatty acid binding protein (I-FABP) as a promising test for Crohn's disease: a preliminary study. Clin. Lab., 2015, 61(1-2), 87-91.

[27] Wiercinska-Drapalo, A., Jaroszewicz, J., Siwak, E., et al.: Intestinal fatty acid binding protein (I-FABP) as a possible biomarker of ileitis in patients with ulcerative colitis. Regul. Pept., 2008, $147(1-3), 25-28$.

[28] Wiest, R., Lawson, M., Geuking, M.: Pathological bacterial translocation in liver cirrhosis. J. Hepatol., 2014, 60(1), 197-209.

[29] Norman, K., Pirlich, M.: Gastrointestinal tract in liver disease: which organ is sick? Curr. Opin. Clin. Nutr. Metab. Care, 2008, $11(5), 613-619$
[30] Saitoh, O., Sugi, K., Lojima, K., et al.: Increased prevalence of intestinal inflammation in patients with liver cirrhosis. World J. Gastroenterol., 1999, 5(5), 391-396.

[31] De Palma, G. D., Rega, M., Masone, S., et al.: Mucosal abnormalities of the small bowel in patients with cirrhosis and portal hypertension: a capsule endoscopy study. Gastrointest. Endosc., 2005, 62(4), 529-534.

[32] Bhonchal, S., Nain, C. K., Prasad, K. K., et al.: Functional and morphological alterations in small intestine mucosa of chronic alcoholics. J. Gastroenterol. Hepatol., 2008, 23(7 Pt 2), e43e48.

[33] Balzan, S., de Almeida Ouadros, C., de Cleva, R., et al.: Bacterial translocation: overview of mechanisms and clinical impact. J. Gastroenterol. Hepatol., 2007, 22(4), 464-471.

[34] Du Plessis, J., Vanheel, H., Janssen, C. E., et al.: Activated intestinal macrophages in patients with cirrhosis release NO and IL-6 that may disrupt intestinal barrier function. J. Hepatol., 2013, $58(6), 1125-1132$.

[35] Sandler, N. G., Koh, C., Roque, A., et al.: Host response to translocated microbial products predicts outcomes of patients with HBV or HCV infection. Gastroenterology, 2011, 141(4), 12201230.

[36] Villa, E., Cammà, C., Marietta, M., et al.: Enoxaparin prevents portal vein thrombosis and liver decompensation in patients with advanced cirrhosis. Gastroenterology, 2012, 143(5), 12531260 .

[37] French, A. L., Evans, C. T., Agniel, D. M., et al.: Microbial translocation and liver disease progression in women coinfected with HIV and hepatitis C virus. J. Infect. Dis., 2013, 208(4), 679689.

(Kocsis Dorottya dr., Budapest, Szentkirályi u. 46., 1088 e-mail: kocsisdorottyal@gmail.com)

\title{
FELHÍVÁS \\ folyóirat-referátumok beküldésére
}

\begin{abstract}
A Semmelweis Egyetem Továbbképző Központjának döntése értelmében
2016. január 1-jétöl folyamatosan orvos-továbbképzési pontokat kaphatnak a nemzetközi, impaktfaktoros folyóiratokban megjelent közlemények rövid összefoglalásának, referátumának beküldöi.
\end{abstract}

Az Orvosi Hetilap hasábjain megjelenő és közlésre elfogadott referátum után 1 pont, félévente maximum 12 továbbképzési pont gyüjthető, amelyet félévente összesitve továbbitunk a továbbképzési központok felé.

Távoktatással szerzett pontokból évente legfeljebb 20 pont számitható be.

Aki továbbképzési pontot kíván gyüjteni, a referátum beküldésekor adja meg pecsétszámát.

Várjuk lelkes, továbbképzési pontokat gyüjteni kivánó referálóink jelentkezését!

A referátum fejlécében az alábbi adatokat kérjük megadni:

\section{A cikk címe magyarul, zárójelben az angol cím}

A szerző(k) neve (vezetéknév, a keresztnevet jelölő betü( $k$ ) - 3 szerzőig, háromnál több szerző esetén et al.), a levelező szerző neve, munkahelye és e-mail címe)

A folyóirat neve - a szokásos nemzetközi rövidítés szerint (PubMed), évszám, kötetszám, füzetszám, a cikk kezdő és utolsó oldalszáma

A referátumot elektronikus úton (Editorial Manager vagy e-mail: edit.budai@akademiai.hu) kérjük elküldeni. 